\title{
KAJIAN SOSIOLOGI SASTRA DAN NILAI PENDIDIKAN KARAKTER DALAM KUMPULAN CERPEN LUKISAN KALIGRAFI KARYA A. MUSTOFA BISRI
}

\author{
Trisnawati \\ Universitas Mathla'ul Anwar, Banten \\ Surel: enatrisna1@gmail.com
}

\begin{abstract}
ABSTRAK
Penelitian ini bertujuan untuk menggambarkan isi karya cerpen dalam kajian sosiologi. Cerpen yang dianalisis juga mengandung banyak nilai pendidikan karakter. Cerpen menceritakan tentang tokoh-tokoh dalam menghadapi kehidupan di lingkungan keluarga dan di lingkungan masyarakat sekitar. Cerpen juga memberikan nilai-nilai pendidikan karakter dalam bertindak atau bersikap yaitu dalam bertutur kata maupun melakukan tindakantindakan yang baik yang sepatutnya dilakukan. Metode yang digunakan dalam penelitian ini yaitu metode kualitatif. Metode kualitatif merupakan metode yang cocok untuk digunakan dalam melakukan penelitian analisis deskriptif. Menurut Syamsudin \& Vismaia, 2011: 73 mengemukakan bahwa penelitian kualitatif merupakan penelitian yang menggambarkan dan menganalisis setiap individu dalam kehidupan dan pemikirannya. Metode kualitatif cocok digunakan dalam mengkaji atau menganalisis sebuah karya sastra agar bisa menganalisis secara mendalam mengenai nilai-nilai yang terkandung dalam sebuah karya sastra. Langkahlangkah dalam melakukan penelitian ini yaitu dengan memilih sebuah karya sastra yang baik untuk dikaji dan di analisis, membaca dan menelaah isi dalam karya sastra, memilah dan memahami nilai-nilai yang terkandung dalam interaksi tokoh cerita, mencatat hasil temuan nilai-nilai yang terkandung dalam cerpen, dan menyimpulkan hasil analisis nilai-nilai cerpen.
\end{abstract}

\section{Keywords: Sosiologi, Nilai Pendidikan Karakter, Cerpen}

\section{A. PENDAHULUAN}

Suatu karya sastra memberikan isi cerita yang didalamnya terkandung cerita-cerita mengenai kehidupan manusia dengan cara berinteraksi dengan keluarga maupun masyarakat di lingkungan sekitar. Karya sastra biasanya seringkali mengangkat ide cerita yaitu dari permasalahan maupun kenyataan dalam kehidupan manusia. Dalam penelitian ini, penulis mencoba untuk mengkaji unsur sosiologi dalam kumpulan cerpen lukisan kaligrafi karya A. Mustofa Bisri dan menganalisis nilai pendidikan karakter yang baik dalam tindakan tokoh cerpen. Dalam hal ini, penulis hanya mengkaji salah satu pendekatan dalam karya sastra cerpen yaitu unsur ekstrinsik. Unsur ekstrinsik yang akan dianalisis adalah unsur sosiologi dalam karya sastra cerpen. Ada beberapa hal yang perlu dikaji dalam unsur ekstrinsik sosiologi yaitu menurut Wellek \& Warren dalam bukunya Theory of Literature (1994: 109133) bahwa sosiologi pengarang berhubungan dengan profesi pengarang dan institusi sastra, 
yaitu masalah yang dikaji antara lain dalam bidang ekonomi, latar belakang sosial, status pengarang, dan ideologi pengarang yang terlihat dari berbagai kegiatan pengarang diluar karya sastra. Dalam sosiologi karya sastra yaitu mengkaji isi karya sastra, tujuan, serta hal-hal lain yang tersirat dalam karya sastra itu sendiri dan berkaitan dengan masalah sosial, sedangkan sosiologi pembaca mengkaji permasalahan pembaca dan dampak sosial karya sastra, serta sejauh mana karya sastra ditentukan dari latar sosial, perubahan dan perkembangan sosial.

Selain mengkaji unsur sosiologi dalam karya sastra cerpen, penulis mencoba mengkaji mengenai nilai pendidikan karakter dalam cerpen. Hal ini, dilakukan penulis untuk menganalisis sikap tokoh dalam cerpen yaitu dalam berinteraksi dengan masyarakat yang erat hubungannya dengan unsur sosiologi dalam sastra. Jadi, penulis membuat simpulan bahwa pendidikan karakter merupakan upaya untuk memajukan budi pekerti dan pikiran seseorang dalam berakhlak baik dan memiliki budi pekerti yang baik pula yang akan menjadikan seseorang atau sekelompok orang bisa bergaul, berinteraksi, berkomunikasi dengan masyarakat di lingkungan keluarga maupun masyarakat sekitar. Dalam mengkaji unsur sosiologi dan nilai pendidikan karakter, penulis mengkaji tokoh cerpen dalam menghadapi berbagai masalah kehidupan. Berbagai masalah dalam kehidupan misalnya masalah ekonomi, strata sosial, tradisi atau adat istiadat, dan sebagainya.

\section{B. KAJIAN TEORI}

Menurut KBBI, 1989: 855 sosiologi sastra merupakan pengetahuan tentang sifat dan perkembangan masyarakat dari atau mengenai sastra. Perkembangan yang dipengaruhi oleh lingkungan masyarakat tempat ia berasal, ideologinya, kondisi ekonomi dan sebagainya. Wellek \& Warren (Semi, 1989: 178) mengemukakan bahwa sosiologi sastra mempermasalahkan suatu karya menjadi pokok, alat tentang apa yang tersirat dalam karya sastra dan apa tujuan serta amanat yang hendak disampaikan, sedangkan menurut Soemanto (1993) menyatakan pemahaman sastra memiliki keterkaitan timbal balik dalam derajat tertentu dengan masyarakat dan sosiologi sastra berupaya meneliti pertautan antara sastra dengan kenyataan masyarakat dalam berbagai dimensinya. Dalam mengkaji sosiologi cerpen ada beberapa pendekatan sastra yang harus dikaji, pendekatan sastra ada dua yaitu secara instrinsik dan ekstrinsik. Unsur instrinsik yaitu meliputi tema, alur, setting, penokohan, gaya bahasa, dan amanat, sedangkan unsur ekstrinsik sastra meliputi unsur luar karya sastra seperti unsur sosiologi yang dialami oleh pengarang karya sastra dan pembaca. 
Adapun nilai pendidikan karakter menurut Diknas (2011) yaitu meliputi sikap religius, jujur, toleransi, disiplin, kerja keras, kreatif, mandiri, demokratis, rasa ingin tahu, semangat kebangsaan, cinta tanah air, menghargai prestasi, bersahabat atau komunikatif, cinta damai, gemar membaca, peduli lingkungan, peduli sosial, dan tanggung jawab. Nilai pendidikan karakter merupakan nilai yang dimiliki oleh setiap orang atau manusia dalam menghadapi dan menjalani kehidupannya yaitu dalam berinteraksi dengan lingkungan keluarga, maupun lingkungan masyarakat sekitar. Dalam mengkaji nilai pendidikan karakter ini penulis akan lebih memahami sikap maupun tindakan yang dilakukan oleh tokoh dalam menjalankan alur cerita yang didalamnya menyangkut berbagai masalah kehidupan yang baik maupun yang buruk. Menurut Ki Hajar Dewantara menyatakan bahwa pendidikan adalah daya upaya untuk memajukan budi pekerti, pikiran, dan jasmani anak agar selaras dengan lingkungan dan masyarakatnya, sedangkan karakter menurut Abdul Majid (2010) yaitu sifat kejiwaan, akhlak atau budi pekerti yang menjadi ciri khas seseorang atau sekelompok orang.

\section{METODE PENELITIAN}

Metode merupakan suatu cara dalam memecahkan permasalahan dalam penelitian. Metode merupakan cara yang dilakukan oleh peneliti bisa berdasarkan pengamatan, wawancara, atau penelaahan dokumen. Metode yang digunakan dalam penelitian ini yaitu metode kualitatif. Metode kualitatif merupakan metode yang cocok untuk digunakan dalam melakukan penelitian analisis deskriptif. Menurut Syamsudin \& Vismaia, 2011: 73 mengemukakan bahwa penelitian kualitatif merupakan penelitian yang menggambarkan dan menganalisis setiap individu dalam kehidupan dan pemikirannya. Penelitian kualitatif merupakan penelitian yang memiliki rancangan yaitu mencoba memperoleh gambaran yang lebih mendalam, memandang peristiwa secara keseluruhan dalam konteksnya dan mencoba memperoleh pemahaman yang holistik, memahami makna, dan memandang hasil penelitian sebagai spekulatif. Dalam mengkaji karya sastra peneliti menggunakan metode kualitatif, karena metode ini sesuai digunakan untuk mengkaji suatu makna dan isi dari sebuah data dalam cerpen, sehingga isi cerpen bisa dikaji atau dianalisis dan akan memperoleh pemahaman yang holistik. Selain metode penelitian, penulis menggunakan teknik dalam mengkaji unsur sosiologi cerpen yaitu dengan menggunakan teknik analisis deskriptif. Menurut Moleong, 2012:11 mengemukakan bahwa deskriptif merupakan cara mengumpulkan data yang meliputi kata-kata, gambar, dan bukan angka. Dalam penelitian ini, penulis mengambil teknik analisis deskriptif dikarenakan tekknik ini sesuai digunakan untuk 
menganalisis atau mengkaji kata-kata dalam cerpen, sehingga bisa mendapatkan pemahaman yang lebih mendalam.

\section{HASIL DAN PEMBAHASAN}

Dalam hasil dan pembahasan, penulis mengkaji unsur sosiologi dan nilai pendidikan karakter dalam kumpulan cerpen lukisan kaligrafi karya A. Mustofa Bisri dengan judul Gus Muslih, Bidadari dibawa Jibril, Lebaran Tinggal Satu Hari Lagi, Lukisan Kaligrafi dan Mbok Yem.

\section{Cerpen 1 Gus Muslih}

\section{a. Unsur Sosiologi}

\section{Menentang Adat Istiadat atau Tradisi}

"Banyak hal yang sudah berjalan lama di daerah kami dihujat dan di pertanyakan oleh Gus Muslih, misalnya, kebiasaan keluarga yang mendapat musibah kematian memberi makan kepada para tamu yang bertakziah dan memberikan uang selawat kepada kiai atau modin ditentang habis-habisan”. (Hal: 13).

\section{Strata Sosial Masyarakat}

"Ya kalau keluarga yang tertimpa musibah itu keluarga yang berada tak masalah, " katanya dalam sebuah ceramahnya. "Kalau keluarga itu miskin, apakah hal itu tidak menambah musibah". (Hal: 14).

\section{Tradisi}

"Wong itu sudah merupakan tradisi sejak lama kok diutik-utik". Itu namanya tidak menghormati orang-orang tua yang mula-mula mentradisikannya”. (Hal: 14).

\section{b. Nilai Pendidikan Karakter}

\section{Kritis, Tegas dan Percaya Diri}

“Gus Muslih adalah seorang kiai muda yang tidak hanya cerdas dan kritis, tapi juga tegas dan lugas. Apabila dia melihat sesuatu yang dianggapnya tidak benar, tanpa ragu dia terang-terangan menyalahkannya”. (Hal: 13).

\section{Beribadah Kepada Tuhan YME}

"Namun sebelum mereka melihat Gus Muslih sedang bersembahyang di mesjid. Mereka menunggu hingga Gus Muslih selesai bersembahyayng dan berdzikir seperti biasanya. (Hal: 16). 


\section{Tolong Menolong}

“Aku turun menghampiri makhluk kecil yang menggelepar-gelepar itu. Tanpa pikir panjang, aku gendong anak anjing itu. Maka aku mencopot jasku dan membungkus anak anjing yang terus menggeletar dalam pangkuanku”. (Hal: 18).

"Alhamdulilah, setelah aku rawat beberapa hari, anak anjing itu sembuh dan sehat. Beberapa hari kemudian Babah ong tetanggaku, memintanya dan aku berikan dengan berpesan padanya untuk merawatnya dengan baik”. (Hal: 20).

Dalam isi cerpen yang berjudul Gus Muslih diceritakan unsur sosiologi bahwa tokoh Gus Muslih sering menentang tradisi yang dianggapnya membebani orang yang terkena musibah, Gus Muslih senantiasa memikirkan strata sosial seseorang pada saat dibebani biaya untuk melakukan tradisi tersebut. Selain kajian sosiologi, nilai pendidikan karakter dalam cerpen Gus Muslih ini menceritakan tentang Gus Muslih yang selalu kritis, tegas dan percaya diri dalam melakukan tindakan. Selain itu, Gus Muslih senantiasa rajin beribadah dan tolong menolong terhadap sesama makhluk hidup, hewan sekalipun.

\section{Cerpen 2 Bidadari Dibawa Jibril}

\section{a. Nilai Sosiologis}

\section{Perhatian Kepada Sesama Muslim atau Masyarakat yang Lain}

"Bila dia melihat kawan perempuannya yang muslimah dia bisa memanggil ukhti jilbabnya kurang rapat, dia langsung menyemprotnya dengan lugas. (Hal: 29-30).

\section{Memberikan Arahan Kepada Masyarakat yang Satu dengan yang Lainnya}

"Hindun selalu bersemangat, apalagi bila sudah bicara, soal kemunkaran dan kemaksiatan yang merajalela di tanah air atau soal bid'ah yang menurutnya banyak dilakukan oleh orang-orang Islam, wah dia akan berkobar-kobar bagaikan banteng luka”. (Hal: 30).

\section{b. Nilai Pendidikan Karakter}

\section{Taat dalam Beribadah}

"Dia memang seorang muslimah taat dari keluarga taat. Meski SD tidak belajar agama di Madrasah, ketaatannya terhadap agama, seperti salat pada waktunya, puasa senin kamis, salat dhuha dan sebagainya, tidak kalah dengan mereka yang dari kecil belajar agama”. (Hal: 29).

\section{Kerja Keras}


"Apabila Hindun melihat atau mendengar ada orang Islam melakukan perbuatan yang menurutnya tidak rasional, langsung dia mencapnya sebagai klemik atau bahkan syirik yang harus diberantas". (Hal: 30).

Dalam cerpen yang berjudul bidadari dibawa Jibril tokoh Hindun memiliki jiwa sosial yang kuat, ia senantiasa memperhatikan keadaan masyarakat sesama muslim terutama dalam hal beribadah, berpakaian, melakukan tindakan yang menyalahi agama. Ia pun senantiasa memberikan arahan kepada masyarakat untuk mencegah kemunkaran dan kemaksiatan yang merajalela di tanah air. Selain unsur sosiologi yang terkandung tokoh Hindun juga memiliki nilai pendidikan karakter yang baik, terlihat dari ia selalu taat beribadah, melakukan apa yang diperintahkan oleh Tuhan YME, selalu bekerja keras dalam membela agama dan menentang perbuatan yang tidak rasional.

\section{Cerpen 3 Lebaran Tinggal Satu Hari Lagi}

\section{a. Unsur Sosiologi}

\section{Adat Istiadat}

"Selama ini, sebagai orang desa yang dikawin orang kota, dia merasa tidak pantas bila bertanya macam-macam urusan lelaki”. (Hal: 57).

\section{Taat Beribadah}

"Sehabis menidurkan anak semata wayangnya, Siti sembahyang isya. Tidak seperti biasanya, kali ini doanya panjang sekali. Semua doa yang dihapalnya dibaca semua, bahkan ditambah doa dengan bahasa ibunya”. (Hal: 58).

\section{Perhatian Kepada Sesama Manusia}

"Dia teringat semua kebaikan suaminya yang selama ini tidak begitu ia perhatikan. Bicaranya selalu lembut kepadanya. Jika pulang dari berpergian, jauh atau dekat, selalu tidak lupa membawa oleh-oleh untuk dirinya dan anak mereka. Bila memberi uang, suaminya tidak pakai hitungan”. (Hal: 58).

\section{b. Nilai Pendidikan Karakter}

\section{Baik dan Tulus}

"Dia teringat semua kebaikan suaminya yang selama ini tidak begitu ia perhatikan. Bicaranya selalu lembut kepadanya”. (Hal: 58).

\section{Tolong-Menolong}

"Tidak jarang suaminya, jika sedang di rumah ikut membantunya, tidak hanya momong anak, tapi juga mencuci dan aktif di dapur. Siti tersenyum sendiri, teringat 
suaminya berlelehan air matanya saat membantunya merajang bawang merah”. (Hal: $58)$.

\section{Sikap Religius}

"Siti tidak bisa membendung tangisnya sambil mengelus-elus anaknya, dia terus mengucapkan doa, “ya Tuhan selamatkan suamiku! Selamatkan suamiku!”. (Hal: 61).

\section{Tanggung Jawab}

"Hei, ada apa ini? terdengar suara lirih, " ada apa dengan suamimu? Ini suamimu telah datang, sayang. Kenapa pintu tidak dikunci? Sengaja menungguku ya? Lihat seperti janjiku, aku datang sebelum lebaran," (Hal: 61).

Dalam cerpen yang berjudul lebaran tinggal satu hari lagi terdapat nilai sosiologis yaitu adat istiadat, taat beribadah, dan perhatian terhadap sesama manusia. Dalam cerita itu diceritakan bahwa tokoh Siti merupakan orang desa yang memiliki adat istiadat bahwa ia tidak pantas untuk bertanya macam-macam akan urusan lelaki. Serta sikap taat beribadah ia tunjukkan pada saat ia gelisah, ia selalu sembahyang dan berdoa kepada Tuhan YME supaya ia lebih tenang dalam menghadapi persoalan hidupnya. Sedangkan tokoh Mat Soleh menunjukkan perhatian kepada keluarga dengan senantiasa memberi nafkah dan membantu istrinya dalam mengurus rumah dan anaknya. Sedangkan nilai pendidikan karakter dalam cerpen ini yaitu sikap baik dan tulus yang ditunjukkan oleh tokoh Mat Soleh dalam bersikap dan senantiasa membantu istrinya, serta nilai pendidikan karakter pada tokoh Siti yaitu sikap religius dan taat beribadah, ketika ia mendapat kesulitan, ia senantiasa berdoa dan dalam akhir cerita Mat Soleh menunjukkan sikap tanggung jawab terhadap istri dan anaknya dalam menepati janji untuk pulang sebelum lebaran.

\section{Cerpen 4 Lukisan Kaligrafi}

\section{a. Unsur Sosiologi}

\section{Bersilaturahmi dengan Masyarakat Lain}

"Menurut Hardi, disamping sillaturahmi, kedatangannya juga di maksudkan untuk berbincang-bincang dengan ustadz Bachri soal kaligrafi”. (Hal: 62).

\section{Berkomunikasi dengan Masyarakat}

“Goresan-goresan sampeyan berkarakter ( "ini apa pula maksudnya?). Ustadz Bachri membatin, tak paham). Kalau bisa, diatas kanvas. Tahu kanvaskan? Betul ya! Tiga bulan lagi kawan"pelukis kaligrafi kebetulan akan pameran. Nanti sampeyan ikut ya, ya?!". (Hal: 64). 


\section{Tradisi Berkomunikasi Secara Terbuka dengan Keluarga}

"Bukankah dia sendiri yang mengajarkan dan memulai tradisi keterbukaan di rumah?” (Hal: 69).

\section{b. Nilai Pendidikan Karakter}

\section{Kreatif}

"Seperti kebanyakan orang seprofesinya, Hardi sangat peka terhadap kehendak pasar. Dia kini melukis apa saja asal laku mahal. Mungkin karena kecerdasannya, dia segera bisa menangkap kelakukan zaman dan mengikutinya. Dia mulai melukis dari perempuan cantik, pembesar negeri, hingga kaligrafi. (Hal: 62).

\section{Bersyukur}

"Ustadz Bachri bersyukur atas kedatangan kawannya yang meskipun agak sok telah memberinya wawasan mengenai kesenian, terutama seni rupa. (Hal: 63).

Dalam cerpen lukisan kaligrafi unsur sosiologi yaitu bersilaturahmi dengan masyarakat lain yaitu tokoh Hardi selalu bersilaturahmi dan berbincang dengan Ustadz Bachri dan ia selalu berkomunikasi dengan masyarakat sedangkan nilai pendidikan karakter yang terdapat dalam cerpen lukisan kaligrafi yaitu sikap kreatif yang ditunjukkan oleh Hardi, ia selalu kreatif dalam membuat lukisan dengan berbagai tema dan tokoh Ustadz Bachri bersyukur atas kedatangan kawannya sehingga ia mengetahui wawasan mengenai kesenian terutama seni rupa.

\section{Cerpen 5 Mbok Yem}

\section{a. Unsur Sosiologi}

\section{Komunikasi dengan Masyarakat}

"Ya, tapi Nak Mus kan pasti pandai bahasa arab, jadi tak akan kesasar dan bisa menolong kita jika belanja, kita tidak perlu lagi menawar-nawar pakai bahasa isyarat, kayak orang bisu." Orang-orang pada ketawa. (Hal: 121).

\section{Taat Beribadah dan Berdoa}

"Aku perhatikan, sejak selesai acara salat dan berdoa bersama hingga akhirnya masing-masing berdzikir dan berdoa sendiri-sendiri, Mbok Yem dan Mbah Joyo terus menangis dan hanya mengulang-ulang. Astagfirulloh---Astagfirulloh, memohon ampun kepada Allah. (Hal: 124).

\section{Peduli Sesama}

“Tenanglah Mbok Yem”, bujuk ibuku sambil merangkul perempuan tua itu, "Mbah Joyo tidak kemana-mana kita pasti akan menemukannya." 
"Iya, Mbok," adikku ikutan membujuk, "kalau pun Mbah Joyo kesasar, di sini ada petugas khusus yang ahli menemukan orang kesasar. Percayalah!” (Hal: 126).

"Aku sendiri dan mungkin juga ibu dan adikku tidak begitu yakin dengan apa yang kami katakan, namun alhamdulilah, meski masih terisak dan bicara sendiri, Mbok Yem bisa agak tenang. “ (Hal: 127).

\section{b. Nilai Pendidikan Karakter}

\section{Bersemangat}

Beberapa orang tampak letih. Justru Mbok Yem dan Mbah Joyo anggota rombongan yang paling tua sedikitpun tidak memperlihatkan tanda-tanda kelelahan. Bahkan pancaran semangat dua sejoli ini tampak jelas seperti mempermuda usia mereka. (Hal: 123).

\section{Tolong Menolong}

"Saya tidak kesasar dan tidak salah naik bus. Saya bertemu dengan seorang muda yang gagah dan ganteng dan diajak naik kendaraannya yang bagus sekali. Saya bilang bahwa saya bersama rombongan kawan dan istri saya. Dia bilang sudah tahu dan meyakinkan saya bahwa nanti saya akan ketemu juga di Mina. Bapak sudah tua, katanya nanti capek kalau naik bus. Akhirnya saya ikut. Sampai di Mina saya dibawa kemari, disuruh istirahat sebentar. Saya tertidur entah berapa lama. Tahu-tahu menjelang subuh saya dibangunkan dan diajak melempar jumrah "aqabah. Setelah itu saya diantar kemari lagi. Sambil meninggalkan buah-buahan ini, dia pamit dan katanya sebentar lagi kalian akan datang. Dan ternyata dia benar”. (Hal: 128).

\section{Percaya Diri}

Rupanya Mbok Yem yakin apa yang dialami Mbah Joyo itu merupakan anugerah Allah yang ada kaitannya dengan amal perbuatannya. (Hal: 129).

\section{Bersyukur}

"Alhamdulilah, Mbah Joyo tidak benar-benar hilang, "kata Mbok Yem mengakhiri ceritanya, "sehingga kami berdua masih berkesempatan menyempurnakan ibadah haji kami. Semoga Allah memudahkan. Setelah selesai nanti, kami ikhlas, kalau yang maha agung hendak memanggil kami kapan saja. Syukur di sini, di tanah suci ini." (Hal: 130).

Dalam analisis unsur sosiologi cerpen yang berjudul Mbok Yem unsur sosiologi yang terdapat dalam cerpen yaitu komunikasi dengan masyarakat terjalin dan ditunjukkan oleh tokoh Mbok Yem yang terlihat cukup akrab dengan orang lain Nak Mus yang baru 
dikenalnya. Kemudian unsur sosiologi juga terdapat dalam hal taat beribadah dan berdoa ditunjukkan oleh Mbok Yem dan Mbah Joyo yaitu mereka tidak henti-hentinya berdzikir dan berdoa serta memohon ampun kepada Allah akan dosa-dosa yang diperbuatnya selama ini. Unsur sosiologi yang ketiga yaitu peduli sesama, kepedulian ditunjukkan pada saat Mbah Joyo hilang, yaitu tokoh Ibu Nak Mus dan adiknya yang tidak henti-hentinya menenangkan Mbok Yem yang gelisah atas kehilangan Mbah Joyo.

Nilai pendidikan karakter yang ditunjukkan dalam cerpen yang berjudul Mbo Yem yang pertama yaitu bersemangat, jiwa semangat ditunjukkan oleh Mbok Yem dan Mbah Joyo dalam menjalani ibadah haji walaupun usia mereka sudah tua, mereka ingin lebih mantap beribadah di tanah suci dan ingin mendapat keberkahannya. Nilai pendidikan karakter yang kedua yaitu tolong menolong terlihat dalam tindakan yang ditunjukkan oleh seorang pemuda ganteng yang menolong Mbah Joyo untuk naik mobilnya yang bagus dan mengantarkan Mbah Joyo ke Mina dengan memberikan makanan dan buah-buahan yang lezat. Sikap yang ketiga percaya diri ditunjukkan oleh Mbok Yem yang percaya dan yakin bahwa yang dialami Mbah Joyo merupakan anugerah yang diberikan Tuhan lewat pemuda ganteng yang mengantarkan Mbah Joyo ke Mina, anugerah yang Mbah Joyo dapatkan karena Mbah Joyo telah menolong Mbok Yem dari dunia kelam menjadi manusia yang taat dan senantiasa bertobat atas dosa-dosa yang dilakukannya. Nilai pendidikan karakter yang terakhir yaitu bersyukur, hal ini ditunjukkan oleh Mbok Yem yang bersyukur bahwa Mbah Joyo tidak benar-benar hilang supaya mereka berdua bisa menjalankan ibadah di tanah suci bersamasama dan menyempurnakan ibadah mereka, dan mereka ikhlas apabila Tuhan mengambil nyawa mereka di tanah suci sekalipun.

\section{E. SIMPULAN}

Cerpen yang dikaji oleh penulis merupakan kumpulan cerpen lukisan kaligrafi karya A. Mustofa Bisri. Cerpen yang dikaji ada lima cerpen yaitu cerpen yang berjudul Gus Muslih, bidadari dibawa Jibril, lebaran tinggal satu hari lagi, lukisan kaligrafi dan Mbok Yem. Kelima cerpen tersebut masing-masing mempunyai unsur sosiologi dan nilai pendidikan karakter yang bisa dijadikan pedoman hidup di masyarakat yaitu di lingkungan keluarga atau di lingkungan masyarakat sekitar. Dalam cerpen 1 yang berjudul Gus Muslih unsur sosiologi yang terdapat dalam cerpen yaitu menentang adat istiadat, strata sosial masyarakat, tradisi, sedangkan nilai pendidikan karakter dalam cerpen Gus Muslih yaitu kritis, tegas dan percaya diri, beribadah kepada Tuhan YME, dan tolong menolong. Cerpen 2 dengan judul bidadari dibawa Jibril mempunyai unsur sosiologi yaitu perhatian kepada sesama muslim atau 
masyarakat yang lain, memberikan arahan kepada masyarakat yang satu dengan yang lain, sedangkan nilai pendidikan karakter yaitu taat dalam beribadah dan kerja keras. Unsur sosiologi dalam cerpen 3 yang berjudul lebaran tinggal satu hari lagi yaitu adat istiadat, taat beribadah dan perhatian kepada sesama manusia, sedangkan nilai pendidikan karakter dalam cerpen yaitu baik dan tulus, saling membantu atau tolong menolong, sikap religius dan tanggung jawab. Cerpen 4 yang berjudul lukisan kaligrafi nilai sosiologi yang terkandung yaitu bersilaturahmi dengan masyarakat lain, berkomunikasi dengan masyarakat, dan tradisi berkomunikasi secara terbuka dengan keluarga, sedangkan nilai pendidikan karakter dalam cerpen lukisan kaligrafi yaitui kreatif dan bersyukur. Cerpen yang terakhir yaitu cerpen ke 5 yang berjudul Mbok Yem memiliki unsur sosiologi yaitu komunikasi dengan masyarakat, taat beribadah dan berdoa, sedangkan nilai pendidikan karakter yaitu bersemangat, tolong menolong, percaya diri dan bersyukur.

Dari kelima cerpen tersebut penulis mendapatkan pemahaman dalam unsur sosiologi yang meliputi interaksi dalam kehidupan bermasyarakat di keluarga maupun di lingkungan masyarakat sekitar sehingga penulis dapat membedakan perilaku atau sikap yang baik atau yang buruk yaitu dalam berinteraksi dengan sesama masyarakat khususnya umat muslim. Selain unsur sosiologi penulis dapat memahami pentingnya nilai pendidikan karakter yang akan memberikan cerminan dalam berkarakter yang baik terhadap sesama masyarakat.

\section{DAFTAR PUSTAKA}

Abdul Majid,. 2010. Pendidikan Karakter dalam Perspektif Islam. Bandung: Insan Citra Utama.

Bisri, A. Mustofa. 2008. Lukisan Kaligrafi. Jakarta: PT. Kompas Media Nusantara.

Departemen Pendidikan Nasional. 1989. Kamus Besar Bahasa Indonesia. Jakarta: Balai Pustaka.

Ki Hadjar Dewantara. 1972. Pendidikan. Yogyakarta: Majelis Luhur Persatuan Taman Siswa. Lexy, J. Moleong. 2012. Metodologi Penelitian Kualitatif. Bandung: PT. Remaja Rosdakarya. Semi, Atar. 1989. Kritik Sastra. Bandung: Angkasa.

Soemanto, Bakti. 1993. Jagat Sastra. Yogyakarta: Media Pressindo.

Vismaia, S \& Syamsuddin, AR. 2011. Metode Penelitian Pendidikan Bahasa. Bandung : PT. Remaja Rosdakarya Offset.

Wellek \& Warren. 1994. Teori Kesusastraan. Jakarta: PT. Gramedia. 